\title{
Corporate Governance and Capital Structure of Small Business Service Firms in India
}

\author{
Amarjit Gill ${ }^{1}$, Nahum Biger ${ }^{2}$, Harvinder S. Mand ${ }^{3} \&$ Charul Shah $^{1}$ \\ ${ }^{1}$ College of Business Administration, Trident University International, 5757 Plaza Drive, Cypress, CA, 90630, \\ USA \\ ${ }^{2}$ School of Business, Academic Center Carmel, Haifa, Israel \\ ${ }^{3}$ Sikh National College, Banga, District Sahid Bhagat Singh Nagar, Pin Code: 144505, East Punjab, India \\ Correspondence: Amarjit Gill, College of Business Administration, Trident University International, 5757 Plaza \\ Drive, Cypress, CA, 90630, USA. Tel: 1-714-816-0366. E-mail: amarjit.gill@trident.edu; agill02@shaw.ca
}

Received: March 15, 2012

Accepted: June 11, $2012 \quad$ Online Published: July 3, 2012

doi:10.5539/ijef.v4n8p83

URL: http://dx.doi.org/10.5539/ijef.v4n8p83

\begin{abstract}
This study examines the relationship between corporate governance and capital structure of small business service firms in India. This study also seeks to extend the findings of Gill et al. (2012). The owners of small business service firms in the Punjab area of India were surveyed to collect data. Subjects were asked about their perceptions, beliefs, and feelings regarding the corporate governance and capital structure of their small business service firms. Results show that CEO Duality, Board Size, Small Business Growth, and Family positively impact on the capital structure of small business service firms in India. This study contributes to the literature on the relationship between corporate governance and capital structure of small business firms. The findings may be useful for small business management consultants.
\end{abstract}

Keywords: CEO tenure, CEO duality, board size, capital structure, small business growth, corporate governance, finance

\section{Introduction}

Small business firms play an important role in the Indian economy. Small business sector comprises $95 \%$ of the total industrial units in India, accounting for $40 \%$ of the total industrial production, $34 \%$ of the national exports, and about 25 million persons of industrial employment (Malepati, 2011, p. 1). Small business firms tend to rely on debt financing. The decision of debt financing instead of equity financing is usually driven by the needs of small business firms and the lack of owners' financial resources. In India, the majority of small business services firms are operated by family members. In the service industry, investment in machinery and equipment is almost non-existent (Gill, Biger, \& Bhutani, 2008) and firms have essentially no tangible assets. Therefore, with no real assets collaterals small business service firms face financing challenges and tend to rely on family financing, trade credits, and bank financing.

Modigliani and Miller (1958) were the first authors to develop a theory of capital structure. Although many scholars have extended their capital structure theory, very few tested the relationship between corporate governance and capital structure of the family businesses. The issues of corporate governance have usually been associated with large and listed firms. Less attention has been paid to the relationship between corporate governance and capital structure of small business firms. To fill the gap, the present study focuses on the link between corporate governance and capital structure of small business service firms in India. Corporate governance, in the context of this study, is defined as the structures, processes, and systems that lead to successful operation of the small business service firm. The majority of the small business firms in India are not listed and boards of the directors consist of family members. In many cases, the CEO is also from the same family. Thus, family has full control on small business firms in India (Gollakota \& Gupta, 2006).

The goals of family business firms are similar to those of larger firms in terms of maximizing shareholders' wealth and having optimal capital structure. An optimal capital structure is defined as capital structure that minimizes chances of bankruptcy and maximizes shareholders' wealth. The issue of optimality of capital structure has been debated for many years and it is still one of the unsolved issues in the corporate finance 
literature. Many theoretical studies and much empirical research have addressed this issue, but there is not yet a fully supported and unanimously accepted theory (Morri \& Beretta, 2008).

At variance with publically traded firms, small business firms face different issues related to such complexities as shorter expected life, presence of estate tax, intergenerational transfer problems, and prevalence of implicit contracts. Problems such as agency and asymmetric information are more complex (Ang, 1992) in the small business industry. The literature proposes a variety of variables that might potentially affect the capital structure of firms. In this study, we chose explanatory variables with reference to alternative capital structure theories and previous empirical work. This study includes five proxy variables for governance: CEO Tenure, CEO Duality, Board Size, Small Business Growth, and Family to examine their relationship with capital structure of firms.

\subsection{Institutional Environment of Small Business and Corporate Governance Structure in India}

Although the Indian legal system provides strong creditor protection, the environment is perceived to be contaminated by corruption, red tape, and regulatory impediments to growth (Gill, Biger, \& Tibrewala, 2010). Since 1991, India has introduced a wide range of changes in laws and regulations in an effort to improve corporate governance and investor protection. The changes in laws and regulations also aimed at minimizing corporate scandals. For example, Indian government implemented Clause 49 regulations. The key mandatory features of Clause 49 regulations deal with the followings: i) composition of the board of directors, ii) the composition and functioning of the audit committee, iii) governance and disclosures regarding subsidiary companies, iv) disclosures by the company, v) CEO/CFO certification of financial results, vi) reporting on corporate governance as part of the annual report, and vii) certification of compliance of a company with the provisions of Clause 49 (Chakrabarti, Megginson, \& Yadav, 2007, p. 14). These changes have forced all firms (small and large) to improve their corporate governance.

\subsection{Relevant Literature Review}

Firms use a mix of debt and equity in order to minimize the cost of capital (Modigliani and Miller, 1958) and maximize owners' wealth. Banks however are reluctant to finance family businesses particularly small business service firms because they lack tangible assets as collaterals. Therefore, small and young firms tend draw capital from internal sources such as family, friends (Gill et al., 2012), and retained earnings. Myers (1984) refers this to a "pecking order" where firms use internally generated funds before they look for external financing. Thus, capital structure of the family business firms differs from the larger publically traded firms.

An examination of the effect of corporate governance in small business firms is fairly new. In the past, corporate governance was examined in the context of large publically traded firms. In such firms, agency problems exist because of the separation between ownership and control. In small business firms the separation is not an important issue because most of these firms are operated by family members. Hart (1995) found that in many cases small and even medium enterprises are made up of only the owner who is the sole proprietor and manager. Most of the small business firms are controlled by families and family members are the members of board of directors. The board and the CEO make financing decisions. Thus, the board of directors is charged with the responsibility of managing small business firms and their operations. Lipton and Lorsch (1992) reported that there is a significant relationship between the board size and capital structure. The CEO duality (the CEO being also the chairman of the board) influences the financing decision of the firm. Fama and Jensen (1983) claim that if board is controlled by the CEO, this implies or signals absence of separation of decision management and decision control.

A limited list of international empirical studies on the relationship between corporate governance and capital structure is described below:

Alba et al. (1998) used data from Thailand and found that ownership concentration is positively linked with leverage.

Wen et al. (2002) collected data from Chinese listed firms and found that the board composition and the CEO tenure are negatively linked with leverage of the firm.

Du and Dai (2005) used data of East Asian firms from 1994-96 and found that controlling owners with little shareholding choose higher debt.

Abor (2007) examined the relationship between corporate governance and capital structure decisions by taking a sample of 22 firms listed on the Ghana Stock Exchange (GSE) during the six-year period (1998-2003). Abor found that capital structure is positively associated with board size, board composition, and CEO duality, and negatively associated with $\mathrm{CEO}$ tenure. 
Antoniou et al. (2008) conducted a study to investigate how firms operating in capital market-oriented economies (the U.K. and the U.S.) and bank-oriented economies (France, Germany, and Japan) determine their capital structure. They found that capital structure of a firm is heavily influenced by the corporate governance practices and exposure to capital markets.

Bodaghi and Ahmadpour (2010) collected data from 50 Iranian firms listed at Tehran Stock Exchange to test the relationship between corporate governance and capital structure. They found a negative relationship between board size and debt to equity ratio. Authors also found that CEO duality does not significantly influence corporate financing behavior.

Saad (2010) took a sample of 126 Malaysian publically listed companies from four industries i) consumer products, ii) industrial products, iii) trading/services, and iv) plantations for the period from 1998 to 2006. Through multiple regression analysis, Saad found i) a negative relationship between CEO duality and capital structure, and ii) positive relationships between board size and capital structure.

Rehman et al. (2010) investigated the relationship between corporate governance and capital structure of randomly selected 19 banks of Pakistan from 2005-2006. They found a positive relationship between board size and capital structure.

Vakilifard et al. (2011) used data from Tehran Stock Exchange (TSE), Iran over the over the period 2005-2010. They found a positive relationship between CEO duality and leverage, and a negative relationship between board size and leverage.

Gill et al. (2012) sampled small business owners from India and found that small business growth and family positively influence capital structure of small business firms.

In summary, literature review shows that CEO tenure, CEO duality, board size, small business growth, and family influence the capital structure of firms. Hence the following hypotheses are formulated:

H1) Capital structure of small business service firms in India is positively affected by the CEO tenure.

H2) Capital structure of small business service firms in India is positively affected by the CEO duality.

H3) Capital structure of small business service firms in India is positively affected by the board size.

H4) Capital structure of small business service firms in India is positively affected by the small business growth.

H5) Capital structure of small business service firms in India is positively affected by family.

Conjecture: There might be CEO gender differences regarding the nature of the relationship between the factors and the financial leverage of small business service firms in India.

\section{Method}

\subsection{Measurement}

Consistent with previous research, the measures were taken from three referent studies, which are based on previous studies in financial economics. All measures pertaining to:

i) CEO Tenure, CEO Duality, and Board Size were adopted from Kyereboah-Coleman (2007),

ii) Small Business Growth were adopted from Zehir et al. (2006), and

iii) Measures pertaining to Capital Structure were adopted from Beattie et al. (2006).

All the scale items were reworded to apply to Indian small business owners and the reliability of these re-worded items was re-tested. Respondents were asked to indicate their agreement with each item, using a five-point Likert scale ranging from "Strongly Disagree" to "Strongly Agree."

CEO Tenure (independent variable) was measured by single item that asked a respondent to describe the number of years he or she has been involved as a CEO in small business. Categorized alternative responses were: i) 0-4 Years, ii) 5-9 Years, iii) 10-30 Years, and iv) 31 Years and Over.

CEO Duality (independent variable) was measured by a single item that asked a respondent to describe if he or she is the Chairman of the board in his/her company. Categorized alternative responses were: 1) Yes and 0) No.

Board Size (independent variable) was measured by a single item that asked a respondent to describe number of directors (decision makers) he or she has in his/her company. Categorized alternative responses were: i) 1-3 directors and ii) 4 and more.

Family (dummy variable) was measured by a single item that asked a respondent to describe the characteristics of their families. Categorized alternative responses were: 0) Single Family and i) Joint Family. 
Small Business Growth (SBG), as the control variable, was operationalized as the extent to which small business owners perceive that sales and market share of their companies have improved over the last three years. These two items were taken from Zehir et al.'s (2006) growth and performance indicators. Attesting to SBG's reliability, a Cronbach alpha calculated on the responses of 29 small business owners who participated in the pre-test of the above scale items was 0.95 .

Capital Structure (CS), as dependent variable, was operationalized as the extent to which small business owners perceive that they maintain a level of financial leverage that i) improves company performance, ii) maximizes cash inflows, iii) minimizes chances of bankruptcy, and iv) indicates long-term survival. Beattie et al. (2006) used thirteen-items which measures appropriate amount of debt. Four items were selected to measure the "CS" variable. Scale items were reworded and the reliability of these re-worded items was re-tested. Attesting to CS's reliability, a Cronbach alpha calculated on the responses of 29 small business owners who participated in the pre-test of the above scale items was 0.89 .

\subsection{Sampling Frame, Questionnaire Distribution, and Collection}

The current study consisted of the population of Indian owners of small business service firms. Indian small business owners living in Punjab area of India were chosen as a sampling frame.

\subsection{Sampling Method, Sampling Issues, and Possible Planned Solutions}

The Punjab area of India was chosen as the research site to collect data. The focal population was comprised of owners of small business service firms in the Punjab area of India. There was no need to translate the survey questions into Punjabi or Hindi since almost all the small business owners can read and write English. In cases of difficulties, researchers were available for translation. The instruction sheet indicated that participants could contact the researchers by telephone and/or email regarding any questions or concerns they might have about the research.

To avoid sampling bias, data collection team members were asked to only choose participants that represent the target population. Non-Indian small business owners were excluded.

To achieve a reasonable convenience sample, an exhaustive list of Indian small business owners' names and telephone numbers was created. Survey questionnaire bundles coupled with an instruction sheet were provided to the surveyors for distribution.

The sample included approximately 600 Indian small business owners. A total of 142 surveys were completed over the telephone (approximately $8 \%$ of the surveys were completed over the telephone), through personal visits, and received by mail. Two surveys were non-usable. The response rate was roughly $23.67 \%$. The remaining cases were assumed to be similar to the selected research participants.

\subsection{Issues Related to Confidentiality of the Research Participants}

All individuals who were approached were ensured that their names will not be disclosed and confidentiality will be strictly maintained. In addition all subjects were asked not to disclose their names on the questionnaire. Since the research was based on the survey questionnaire owners of small business service firms were not forced to respond to each specific question.

The Consent Letter specifically indicated that by completing the survey, subjects have consented to participate in the study. Any information that was obtained in connection with this study and that can be identified with subjects will remain confidential and will be disclosed only with subjects' permission or as required by law.

\section{Analysis and Results}

Table 1, 2, and Table 3 show descriptive statistics. The explanation descriptive statistics is as follows:

Skewness: Within the range of: -0.721 to -1.361 (see Table 1)

Kurtosis: Within the range of: 0.455 to 1.466 (see Table 2) 
Table 1.

\begin{tabular}{lccccccc}
\hline Descriptive Statistics & & & & & & & \\
& Min & Max & Mean & SD & Variance & Skewness & Kurtosis \\
\hline SBG1) Sales of my company has gone up over last three years. & 1 & 5 & 3.81 & 1.031 & 1.063 & -1.361 & 1.466 \\
SBG2) Market share of my company has gone up over three years. & 1 & 5 & 3.64 & 0.998 & 0.996 & -0.844 & 0.455 \\
\hline I maintain a level of leverage that... & & & & & & & \\
\hline CS1) ... Improves company performance. & 1 & 5 & 3.82 & 0.900 & 0.810 & -0.721 & 0.463 \\
CS2) ... Maximizes cash inflows. & 1 & 5 & 3.73 & 0.928 & 0.861 & -0.801 & 0.754 \\
CS3) ... Minimizes chances of bankruptcy. & 1 & 5 & 3.86 & 0.956 & 0.915 & -1.110 & 1.372 \\
CS4) ... Indicates long-term survival. & 1 & 5 & 3.87 & 0.966 & 0.933 & -0.953 & 0.857 \\
\hline
\end{tabular}

Min $=$ Minimum

Max $=$ Maximum

$\mathrm{SD}=$ Standard Deviation

$\mathrm{SBG}=$ Small Business Growth

$\mathrm{CS}=$ Capital Structure

Varimax rotation: $84.63 \%$ (see Table 2)

Factor analysis: All the items loaded on the expected factors (see table 3)

Table 2.

\begin{tabular}{|c|c|c|c|}
\hline \multicolumn{4}{|c|}{ Total Variance Explained } \\
\hline & \multicolumn{3}{|c|}{ Rotation Sums of Squared Loadings } \\
\hline Component & Total & $\%$ of Variance & Cumulative $\%$ \\
\hline 1 & 3.250 & 54.162 & 54.162 \\
\hline 2 & 1.828 & 30.470 & 84.632 \\
\hline
\end{tabular}

Extraction Method: Principal Component Analysis.

Table 3.

\begin{tabular}{l|rr}
\hline Rotated Component Matrix $^{\text {a }}$ & \multicolumn{2}{c}{ Component } \\
\hline & \multicolumn{2}{r}{2} \\
\cline { 2 - 3 } SBG1) Sales of my company has gone up over last three years. & 0.212 & $\mathbf{0 . 9 1 0}$ \\
SBG2) Market share of my company has gone up over three years. & .0198 & $\mathbf{0 . 9 1 4}$ \\
& & \\
I maintain a level of leverage that...: & & \\
CS1) ... Improves company performance. & & \\
CS2) ... Maximizes cash inflows. & $\mathbf{0 . 8 9 1}$ & 0.186 \\
CS3) ... Minimizes chances of bankruptcy. & $\mathbf{0 . 8 8 0}$ & 0.211 \\
CS4) ... Indicates long-term survival. & $\mathbf{0 . 8 8 4}$ & 0.232 \\
\hline
\end{tabular}

Notes: ${ }^{a}$ Extraction Method: Principal Component Analysis

Rotation Method: Varimax with Kaiser Normalization

Rotation converged in 3 iterations 
Cronbach Alpha of SBG: 0.856

Cronbach Alpha of CS: 0.93

The question subsets were analyzed in order to enable the calculation of the weighted factor scores. In terms of these weighted factor score items: two SBG and four CS, loaded approximately equally.

\subsection{Pearson Bivariate Correlation Analysis}

Table 4 shows that Capital Structure (CS) is positively correlated with CEO Duality (CD), Board Size (BS), Small Business Growth (SBG), and Family. CEO Tenure (Tenure) was not found to be significant.

Table 4.

\begin{tabular}{|c|c|c|c|c|c|c|}
\hline \multicolumn{7}{|c|}{ Pearson Bivariate Correlation Analysis } \\
\hline & $\mathrm{CS}$ & Tenure & $\mathrm{CD}$ & BS & SBG & Family \\
\hline $\mathrm{CS}$ & 1 & 0.144 & $0.221 * *$ & $0.254 * *$ & $0.428^{* *}$ & $0.265^{* *}$ \\
\hline Tenure & & 1 & -0.020 & 0.148 & 0.149 & 0.074 \\
\hline $\mathrm{CD}$ & & & 1 & -0.126 & $0.251 * *$ & -0.146 \\
\hline BS & & & & 1 & 0.067 & $0.320 * *$ \\
\hline SBG & & & & & 1 & $0.209 *$ \\
\hline Family & & & & & & 1 \\
\hline
\end{tabular}

**Correlation is significant at the 0.01 level (2-tailed)

*Correlation is significant at the 0.05 level (2-tailed)

\subsection{Regression Analysis to Test Hypotheses}

Regression analysis section presents the empirical findings regarding the relationships between Tenure, $\mathrm{CD}, \mathrm{BS}$, SBG, Family, and CS of small business service firms in India.

It was hypothesized that:

i) Capital structure of small business service firms in India is positively affected by the CEO tenure.

ii) Capital structure of small business service firms in India is positively affected by the CEO duality.

iii) Capital structure of small business service firms in India is positively affected by the board size.

iv) Capital structure of small business service firms in India is positively affected by the small business growth.

v) Capital structure of small business service firms in India is positively affected by family.

Positive relationships between i) CD and CS, ii) BS and CS, iii) SBG and CS, and iv) Family and CS were found (see Table 5). These factors predict the capital structure of small business service firms in India. A non-significant relationship between Tenure and CS was found. The CEO tenure does not impact on capital structure of small business service firms in India. 
Table 5.

\begin{tabular}{|c|c|c|c|c|c|c|c|c|}
\hline \multicolumn{9}{|c|}{ Regression Coefficients $\mathrm{a,b,c}$} \\
\hline \multicolumn{9}{|c|}{$\mathrm{R}^{2}=0.281 ;$ Adjusted $\mathrm{R}^{2}=0.255 ; \mathrm{SEE}=0.863 ; \mathrm{F}=10.49 ;$ ANOVA's Test Sig. $=0.000$} \\
\hline \multicolumn{9}{|c|}{ Regression Equation: $\mathrm{CS}=-1.168+0.007 *$ Tenure $+0.456 * \mathrm{CD}+0.254 * \mathrm{BS}+0.327 * \mathrm{SBG}+0.315 *$ Family } \\
\hline & \multicolumn{2}{|c|}{ Unstandardized Coefficients } & \multicolumn{4}{|c|}{ Standardized Coefficients ${ }^{c}$} & \multicolumn{2}{|c|}{ Collinearity Statistics } \\
\hline & $\mathrm{B}$ & Std. Error & Beta & & $\mathrm{t}$ & Sig. & Tolerance & VIF \\
\hline (Constant) & -1.168 & 0.310 & & & -3.765 & 0.000 & & \\
\hline Tenure & 0.007 & 0.009 & & 0.058 & 0.779 & 0.438 & 0.957 & 1.045 \\
\hline $\mathrm{CD}$ & 0.456 & 0.189 & & 0.188 & 2.417 & 0.017 & 0.887 & 1.127 \\
\hline BS & 0.254 & 0.101 & & 0.197 & 2.519 & 0.013 & 0.876 & 1.142 \\
\hline SBG & 0.327 & 0.079 & & 0.327 & 4.131 & 0.000 & 0.857 & 1.167 \\
\hline Family & 0.315 & 0.161 & & 0.156 & 1.952 & 0.053 & 0.836 & 1.196 \\
\hline
\end{tabular}

\footnotetext{
${ }^{a}$ Dependent Variable: CS

${ }^{\mathrm{b}}$ Independent Variables: Tenure, CD, BS, SBG, and Family

${ }^{\mathrm{c}}$ Linear Regression through the Origin

$\mathrm{SEE}=$ Standard Error of the Estimate

Tenure $=\mathrm{CEO}$ tenure

$\mathrm{SBG}=$ Small business growth

$\mathrm{CS}=$ Capital structure
}

Note that all the variance inflation factor (VIF) coefficients are less than 2 and tolerance coefficients are greater than 0.50. Also note that Family, Tenure, CD, BS, and SBG explain $28.1 \%$ of the variance in CS (see Table 5).

\section{Discussion, Limitations, and Future Research}

\subsection{Discussion}

The purpose of this study was to examine the perceived relationships between corporate governance and capital structure (CS) of small business service firms in India. Findings of this study show that CS of small business service firms is positively associated with CD, BS, SBG, and Family (see Table 5). These results lend some support to the findings of Alba et al. (1998), Du and Dai (2005), Abor (2007), Antoniou et al. (2008), Saad (2010), Rehman et al. (2010), Vakilifard et al. (2011), and Gill et al. (2012). The results of this study contradict with the findings of Wen et al. (2002), Abor (2007), Bodaghi and Ahmadpour (2010), Saad (2010), Vakilifard et al. (2011).

The different results may be attributed to the fact that the above studies are related to larger firms from different countries. In addition, large board size and large family means more financial and operational support to small business service firms, which in turn, help increasing the capacity of small business firms to make liability payments. The CEO duality increases CEO experience in small business management. Small business growth increases revenues and profitability, which in turn, help paying debt down.

Table 6 shows the summary of previous authors' findings. 
Table 6.

\begin{tabular}{|c|c|c|}
\hline \multicolumn{3}{|c|}{ Previous Findings Related to Corporate Governance and Capital Structure } \\
\hline Author & Findings & Country \\
\hline Alba et al. (1998) & Found that ownership concentration is positively linked with leverage. & Thailand \\
\hline Wen et al. (2002) & $\begin{array}{l}\text { Found that the board composition and the CEO tenure are negatively linked } \\
\text { with leverage of the firm. }\end{array}$ & China \\
\hline Du and Dai (2005) & Found that controlling owners with little shareholding choose higher debt. & East Asia \\
\hline Abor (2007) & $\begin{array}{l}\text { Found that capital structure is positively associated with board size, board } \\
\text { composition, and CEO duality, and negatively associated with CEO tenure. }\end{array}$ & Ghana \\
\hline Antoniou et al. (2008) & $\begin{array}{l}\text { Found that capital structure of a firm is heavily influenced by the corporate } \\
\text { governance practices and exposure to capital markets. }\end{array}$ & $\begin{array}{l}\text { North America and } \\
\text { Europe }\end{array}$ \\
\hline $\begin{array}{l}\text { Bodaghi and Ahmadpour } \\
\text { (2010) }\end{array}$ & $\begin{array}{l}\text { Found a negative relationship between board size and debt to equity ratio. } \\
\text { Authors also found that CEO duality does not significantly influence }\end{array}$ & Iran \\
\hline & $\begin{array}{l}\text { corporate } \\
\text { financing behavior. }\end{array}$ & \\
\hline Saad (2010) & $\begin{array}{l}\text { Found a negative relationship between CEO duality and capital structure, } \\
\text { and } \\
\text { a positive relationship between board size and capital structure. }\end{array}$ & Malaysia \\
\hline Rehman et al. (2010) & Found a positive relationship between board size and capital structure. & Pakistan \\
\hline Vakilifard et al. (2011) & $\begin{array}{l}\text { Found a positive relationship between CEO duality and leverage, and } \\
\text { a negative relationship between board size and leverage. }\end{array}$ & Iran \\
\hline Gill et al. (2012) & $\begin{array}{l}\text { Found that small business growth and family positively influence capital } \\
\text { structure of small business firms. }\end{array}$ & India \\
\hline
\end{tabular}

In conclusion, the CEO duality, board size, small business growth, and family positively impact on the capital structure of small business service firms in India. Findings also show that joint family system in India lead to larger board size and high small business growth. Although, large board size may not in the favor of small business service firms because it has negative impact on decision making, joint family system is in the favor of small business service firms for their growth (see Table 4). The CEO duality and large board size lead to high debt which is not in the favor of small business service firms because it increases chances of bankruptcy. Therefore, CEO duality should be used with caution and small business firms should have optimal board size based on the firm size.

\subsection{Limitations}

The sample size is small. Because we used survey questionnaire to collect data, respondents could not provide additional information which could have been useful. Also surveys were dropped off which led to low response rate.

\subsection{Future Research}

Because this study is limited to perceptions and intentions, the relationship between independent and dependent variable that we found may suffer from common factor bias, as the questions were parts of the same data collection instrument. Future research should test the relationships between corporate governance and capital structure small business firms through different samples from different industries (e.g., manufacturing and transportation) and different countries (e.g., Canada and United Kingdom). The impact of cultures on capital structure should be explored. Data collection methods such as interview method should also be used to improve the validity of data.

\section{References}

Abor, J. (2007). Corporate governance and financing decisions of Ghanaian listed firms. Corporate Governance, 7(1), 83 - 92. 
Alba, P., Claessens, S., \& Djankov, S. (1998). Thailand's corporate financing and governance structures: Impact on firm's competitiveness', Conference on Thailand's Dynamic Economic Recovery and Competitiveness 20-21 May 1998, UNCC, Bangkok, 1-26. [Online] Available: http://econ.tu.ac.th/class/archan/RANGSUN/MB\%20663/MB\%20663\%20Readings/\%E0\%B9\%93.\%20\%E 0\%B8\%9A\%Е0\%B8\%A3\%Е0\%B8\%A3\%Е0\%B8\%A9\%Е0\%B8\%B1\%Е0\%B8\%97\%Е0\%B8\%A0\%Е0\% B8\%B4\%E0\%B8\%9A\%E0\%B8\%B2\%E0\%B8\%A5/Corporate\%20Governance/Thailand/Thailand's\%20Co rporate $\% 20$ Financing\% $\%$ and $\% 20$ Governance $\% 20$ Structures.pdf (April 22, 2012)

Ang, J. S. (1991). Small business uniqueness and the theory of financial management. Journal of Small Business Finance, 1(1), 1-13.

Ang, J. S. (1992). On the theory of finance for privately held firms. Journal of Small Business Finance, 1(3), 185-203.

Antoniou, A., Guney, Y., \& Paudyal, K. (2008). The Determinants of Capital Structure: Capital Market Oriented versus Bank Oriented Institutions. Journal of Financial and Quantitative Analysis, 43(1), 59-99.

Beattie, V., Goodacre, A., \& Thomson, S. J. (2006). Corporate financing decisions: UK survey evidence. Journal of Business Finance and Accounting, 33(9/10), 1402-1434. http://dx.doi.org/10.1111/j.1468-5957.2006.00640.x

Bodaghi, A., \& Ahmadpour, A. (2010). The effect of corporate governance and ownership structure on capital

Chakrabarti, R., Megginson, W. L., \& Yadav, P. K. (2007). Corporate Governance in India. CFR-Working Paper NO. 08-02, 1-25. http://www.cfr-cologne.de/download/workingpaper/cfr-08-02.pdf (Accessed May 29, 2012)

Du, J., \& Dai, Y. (2005). Ultimate corporate ownership structures and capital structures: Evidence from East Asian Economies. Corporate Governance: An International Journal, 13(1), 60-71.

Fama, E., \& Jensen, M. (1983). Separation of ownership and control. Journal of Law and Economics, 26(2), 301-325.

Gill, A., Biger, N., \& Bhutani, S. (2008). Corporate performance and the chief executive officer's compensation in the service industry. The Open Business Journal, 1, 62-66. http://dx.doi.org/10.2174/1874915100801010062

Gill, A., Biger, N., \& Tibrewala, R. (2010). Understanding and mitigating direct investment-risk in the Indian real estate market. Business and Economics Journal, 1-10.

Gill, A., Mand, H. S., Sharma, S. P., \& Mathur, N. (2012). Factors that influence financial leverage of small Business firms in India. International Journal of Economics and Finance, 4(3). 33-45. http://dx.doi.org/10.5539/ijef.v4n3p33

Gollakota, K., \& Gupta, V. (2006). History, ownership forms and corporate governance in India. Journal of Management History, 12(2), 185-198. http://dx.doi.org/10.1108/13552520610654078

Hart, O. (1995). Corporate governance: Some theory and implications. The Economic Journal, 105(430), 678-689. http://dx.doi.org/10.2307/2235027

Kyereboah-Coleman, A. (2007). Corporate governance and firm performance in Africa: A dynamic panel data analysis. A paper prepared for the "International Conference on Corporate Governance in Emerging Markets.

[Online]

Available: http://www.ifc.org/ifcext/cgf.nsf/AttachmentsByTitle/PS2.3/\$FILE/Kyereboah-Coleman\%2B-\%2BCorpora te\%2BGovernance.pdf (April 22, 2012)

Lipton, M., \& Lorsch, J. W. (1992). A modest proposal for improved corporate governance. Business Lawyer, 48(1), 59-77.

Malepati, V. R. (2011). The performance of small scale industries (SSIs) in India: An overview. Working Paper Series, pp. 1-13. Obtained through the Internet: http://papers.ssrn.com/sol3/papers.cfm?abstract_id=1737836 [accessed 14/5/2012]

Modigliani, F., \& Miller, M. (1958). The cost of capital, corporation finance and the theory of investment. The American Economic Review, 48(3), 261-97.

Morri, G., \& Beretta, C. (2008). The capital structure determinants of REITs. Is it a peculiar industry? Journal of European Real Estate Research, 1(1), 6-57. http://dx.doi.org/10.1108/17539260810891488 
Myers, S. C. (1984). The capital structure puzzle. Journal of Finance, 39, 575-92. http://dx.doi.org/10.2307/2327916

Rehman, M. A., Rehman, R. U., \& Raoof, A. (2010). Does corporate governance lead to a change in the capital structure? American Journal of Social and Management Sciences, 1(2), 191-195. http://dx.doi.org/10.5251/ajsms.2010.1.2.191.195

Saad, N. M. (2010). Corporate Governance Compliance and the Effects to Capital Structure in Malaysia. International Journal of Economics and Finance, 2(1), 105-114.

structure of Iranian listed companies. 7th International Conference on Enterprise Systems, Accounting and Logistics (7th ICESAL 2010) 28-29 June 2010, Rhodes Island, Greece, 89-96. [Online] Available: http://www.icesal.org/2010\%20PROCEEDINGS/docs/P8.pdf (April 22, 2012).

Vakilifard, H. R., Gerayli, M. S., Yanesari, A. M., \& Ma'atoofi, A. R. (2011). Effect of Corporate Governance on Capital Structure: Case of the Iranian Listed Firms. European Journal of Economics, Finance and Administrative Sciences, 35, 165-172.

Wen, Y., Rwegasira, K., \& Bilderbeek, J. (2002). Corporate governance and capital structure decisions of the Chinese Listed Firms. Corporate Governance: An International Review, 10, 75-83. http://dx.doi.org/10.1111/1467-8683.00271.

Zehir, C., Acar, A. Z., \& Tanriverdi, H. (2006). Identifying organizational capabilities as predictors of growth and business performance. The Business Review, 5(2), 109-116. 